\title{
Ethical Management in Companies in the Czech Republic and Ukraine - Comparison of the Presence of a Code of Ethics
}

\author{
Zdeněk Caha, ${ }^{1, *}$ \\ ${ }^{1}$ Department of Management, Faculty of Corporate Strategy, The Institute of Technology and \\ Business, Okružní 517/10, 37001 České Budějovice, Czech Republic
}

\begin{abstract}
The aim of the study is to compare the commonness of a code of ethics as the most important ethical management tool in the business sector in two post-communist countries, namely the Czech Republic and Ukraine. The hypothesis that a code of ethics is much more widespread in the economically more developed country, which is the Czech Republic, and also the assumption that the occurrence of a code of ethics is in relation to the company size, were examined on the base of a questionnaire survey. The results definitely confirmed that a code of ethics is much more widespread in the Czech Republic than in Ukraine. The survey results have also confirmed that the commonness of a code of ethics grows with the company size. This was not confirmed in micro and small companies in Ukraine.
\end{abstract}

Key words: code of ethics, management, commonness, Ukraine, Czech Republic

\section{Introduction}

Ho and Oladinrin [1]; Kaptein [2] show, a code of ethics is a basic element of the ethical infrastructure of an organization. Its acceptance covers the application of formal documents, in which the explicit declaration of the values that should steer the behaviour of employees and managers and support good practices and indicators related to the core of the organization, can be found.

The first studies into codes of ethics were conducted in the USA in the 1950s and 1960s. In the 1950 s, only $15 \%$ of large companies had adopted a code of ethics. This number grew relatively fast over the following decades, so that by the 1960s this number had increased to $40 \%$, by the 1980 s to $75 \%$, and by the 1990 s to $93 \%$ [3]. A Business Ethics Centre report published in 1990 contained very interesting information. It indicated that in 1986, 93\% of companies were acquainted with codes of ethics, which represented a $10 \%$ increase compared to 1979 [4]. Ethics Resource Center research, which was conducted among 747 respondents [5], revealed that nearly $75 \%$ of the companies had a code of ethics in place,

\footnotetext{
* Corresponding author: caha@mail.vstecb.cz
} 
and that this proportion was $57 \%$ among smaller companies with less than 100 employees. In 2001, in a study conducted by KPMG in South Africa, $86 \%$ of companies had a code of ethics in place [6]. In 2003, in research conducted by Deloitte [7], which involved 373 respondents, $83 \%$ of the companies in the USA had a code of ethics in place. The results of a National Business Ethics Survey published in 2005 [8], showed that $86 \%$ of companies used a code of ethics. In $200679 \%$ of companies used a code of ethics [9]. A global survey carried out by KPMG [10] points to the global trend for increasing numbers of companies to define and implement a code of ethics. The survey showed that in 2008 the percentage of companies with a code of ethics increased to $86 \%$.

It is clear from the above that in last few years that a code of ethics has become a basic tool for ethical management within large and well-known companies. This premise is backed up by an informal study conducted by the Institute of Business Ethics (IBE) in 2012 , which showed that a code of ethics was applied by $92 \%$ of those companies with the highest market capitalization based in Great Britain whose shares are traded on the London Stock Exchange [11]. The IBE survey [12] also revealed that in 2012, 73\% of all companies used a code of ethics. The CGMA [13] conducted research in which nearly 2,500 respondents from ten countries took part. The results indicated that the proportion of companies with a code of ethics stood at 82\% (and among large companies 93\%). In 2016, a wide-reaching study conducted by $\mathrm{PwC}$, the largest of its kind, in which 6,337 companies from 115 countries participated (of which 79 prominent companies from the Czech Republic), showed that on average $82 \%$ of companies had an officially established code of ethics [14]. In 2016, Dow Jones and Metricstream [12] jointly conducted one of the most recent surveys, which revealed that $96 \%$ of the 330 questioned companies had established a code of ethics.

The aforementioned surveys point to the growing trend towards the introduction of codes of ethics in business practice. Nonetheless, it is important to note that not all these surveys are compatible. In fact, the results were determined on the basis of numerous factors that were specific to the structure of the respondents. Although a higher proportion of large US based companies have codes of ethics, this proportion is smaller for small and medium-sized companies and companies operating in Asia. It is clear that only global studies that include large numbers of respondents from all business sectors and companies of different sizes will provide the relevant information required. Unfortunately, such surveys are challenging to realize.

A survey conducted by the Association of Chartered Certified Accountants, found that one in five executives or bookkeepers in the Czech Republic had had to deal with a serious ethical dilemma in their work. This only confirms the need to apply effective ethical management tools [15]. On the basis of smaller less representative survey conducted in 2002, in which 60 respondents participated from middle and top management in companies operating in Prague and Central Bohemia, that $35 \%$ of the examined companies had a code of ethics in place and $22 \%$ were considering preparing and applying one [16]. In contrast, Transparency International - Czech Republic and the Economic University in Prague, jointly conducted a very representative survey in 2005 , which was subsequently repeated in 2006 [17]. The surveys sought to determine to what degree codes of ethics were applied by companies that operated on the Czech market. The conclusion was that in the second half of 2005 only 59 (i.e. $10.3 \%$ ) of the 574 companies in the sample set had a code of ethics in place. This state of affairs was similar when the survey was repeated in the first half of 2006, whereby only 104 (i.e. $8.4 \%$ ) of the 1,240 companies in the sample set had a code of ethics in place. The survey also showed that there was a relationship between company size and the presence of a code of ethics. The larger the company the greater the chance a code 
of ethics had been put in place. For example, in 2006, less than $5 \%$ of small companies (i.e. with less than 50 employees) had a code of ethics, whereas this percentage among large companies (i.e. with 300 or more employees) topped $24 \%$. In 2011 , less than $15 \%$ of domestic companies had a code of ethics in place [18]. According to a survey conducted by Transparency International in 2013, this percentage had increased to $46 \%$ of domestic companies. This compares poorly with the world average of 74\% [19]. According to the respondents of a questionnaire survey conducted in 2015, the results of which were processed by the Financial and Economic Institute, $68 \%$ of companies had a code of ethics in place, but only $23 \%$ of companies saw the code of ethics as an obligatory set of rules [20]. According to the previously mentioned PwC survey, in which 6,337 organizations from 115 countries took part, $86 \%$ of the 79 prominent Czech companies questioned had an officially established code of ethics. Unfortunately, the low number and the size of the companies involved belies reality [11].

Despite these results, the number of companies in the Czech Republic that are establishing a code of ethics is gradually growing, although the numbers remain well below the worldwide average (which is higher than 70\%). This gives the impression that the presence of a code of ethics in the Czech Republic tends to be limited to larger companies and public institutions and that this may also be dependent on market activities or economic results of companies [21, 22]. As far as Ukraine is concerned, no extensive research on the presence of codes of ethics is known to the author of this paper. However, it is assumed that the presence of codes of ethics is not as high in Ukraine as in the Czech Republic because the country has a less developed economy. It is also assumed that the presence of codes of ethics is an attribute of more developed economies, where a more cultured business environment exists.

\section{Methodology of the statistical assessment}

The following hypothesis was formulated and tested:

"The presence of a code of ethics is much more widespread in the Czech Republic than in Ukraine, irrespective of company size (micro-, small, medium sized and large companies), and the presence of a code of ethics increases in relation to company size".

Quantitative research was conducted on the basis of a larger questionnaire survey which was conducted between June 2016 and February 2017. The aim of the survey was to obtain a statistically representative cross-sectional data set on small, medium-sized and large companies in the Czech Republic and Ukraine. The data is stored in a pvz.xlsx file and is available at the author. The data was collected on the basis of an electronic questionnaire.The results of the questionnaire survey provided sample sets of 607 companies from the Czech Republic and 145 companies from Ukraine for the analysis. The companies in both sample sets were divided into four groups according to size: large companies (250 or more employees), medium-sized companies (50-249 employees), small companies (10-49 employees) and micro-companies (less than 10 employees). As the task was only to compare the presence of codes of ethics in companies from both countries, we combined the negative answers to the question "Does your company have a code of ethics?" into one answer "No" (the offered options were: "No, we do not miss having it" and "No, we miss having it"). Some companies did not answer this question at all. In such cases, we assigned "No" to the missing answer because it could be realistically assumed that a code of ethics was not in place in the company.

For the sample sets prepared in this way, we prepared tables of absolute and relative frequencies for the answers, as well as column graphs of relative frequencies according to 
both company size and country. As the absolute numbers of companies from both countries differed substantially, relative frequencies were compared i.e. the proportions of companies that have codes of ethics in place to all the companies in the sample set.

The comparisons between Czech and Ukrainian companies were conducted separately for the individual sample sets by means of a two-selection test for the differences in proportions. The first aim was to determine whether the presence of a code of ethics is more frequent in Czech companies than in Ukrainian ones. This was done by testing the hypothesis to see whether the proportion of Czech companies with a code of ethics in place is statistically significantly higher than the proportion of Ukrainian companies. From the point of view of the statistical test itself, it involved the analysis of a zero hypothesis. In other words, whether the difference between the companies with a code of ethics in the Czech Republic and in Ukraine is statistically insignificant, against the alternative that it is statistically significantly higher than 0 . The tested difference was set according to the main hypothesis as the "proportion of Czech companies minus the proportion of Ukrainian companies". A one-sided interval estimation calculation was also performed on the difference in proportions to gain a concrete idea of the size of the difference. The second aim was to determine whether the proportion of companies that have a code of ethics in place grows in relation to company size. For this purpose, a two-sided interval estimation calculation was performed on the proportion of companies with a code of ethics in place according to both company size and country. The intervals are presented graphically (see Figures 1 and 2). Conclusions were subsequently drawn on the basis of the results.

All the statistical tests and calculations for the interval estimations were carried out with a confidence level of $95 \%$ i.e. at a significance level of 0.05 . The outputs are presented in the form of the values of the testing statistics, p-values, lower limits of the one-sided interval estimations and both the upper and lower limits of the two-sided interval estimations. The two-sided interval estimations are presented graphically for visual comparison purposes. The frequency tables and the column graphs were prepared by means of MS Excel, the statistical tests and calculations of the interval estimations using $\mathbf{R}$ statistical software, and the graphical representation of the two-sided interval estimations using Geogebra software.

\section{Results of the statistical processing}

a) Absolute numbers and relative frequencies

Table 1. Presence of a code of ethics in Czech companies (absolute numbers)

\begin{tabular}{|c|c|c|c|}
\hline \multirow{2}{*}{ Company size } & \multicolumn{3}{|c|}{ Presence of a code of ethics } \\
\cline { 2 - 4 } & Yes & No & Total \\
\hline Micro-companies & 17 & 124 & 141 \\
\hline Small companies & 42 & 137 & 179 \\
\hline Medium-sized companies & 59 & 105 & 164 \\
\hline Large companies & 82 & 40 & 122 \\
\hline
\end{tabular}


Table 2. Presence of a code of ethics in Czech companies (relative frequencies)

\begin{tabular}{|l|c|c|}
\hline \multirow{2}{*}{ Company size } & \multicolumn{2}{|c|}{ Presence of a code of ethics } \\
\cline { 2 - 3 } & Yes & No \\
\hline Micro-companies & $12.1 \%$ & $87.9 \%$ \\
\hline Small companies & $23.5 \%$ & $76.5 \%$ \\
\hline Medium-sized companies & $36.0 \%$ & $64.0 \%$ \\
\hline Large companies & $67.2 \%$ & $32.8 \%$ \\
\hline
\end{tabular}

Table 3. Presence of a code of ethics in Ukrainian companies (absolute numbers)

\begin{tabular}{|l|c|c|c|}
\hline \multirow{2}{*}{ Company size } & \multicolumn{3}{|c|}{ Presence of a code of ethics } \\
\cline { 2 - 4 } & Yes & No & Total \\
\hline Micro-companies & 2 & 26 & 28 \\
\hline Small companies & 2 & 29 & 31 \\
\hline Medium-sized companies & 5 & 50 & 55 \\
\hline Large companies & 8 & 23 & 31 \\
\hline
\end{tabular}

Table 4. Presence of a code of ethics in Ukrainian companies (relative frequencies)

\begin{tabular}{|l|c|c|}
\hline \multirow{2}{*}{ Company size } & \multicolumn{2}{|c|}{ Presence of a code of ethics } \\
\cline { 2 - 3 } & Yes & No \\
\hline Micro companies & $7.1 \%$ & $92.9 \%$ \\
\hline Small companies & $6.5 \%$ & $93.5 \%$ \\
\hline Medium-sized companies & $9.1 \%$ & $90.9 \%$ \\
\hline Large companies & $25.8 \%$ & $74.2 \%$ \\
\hline
\end{tabular}

b) Presence of a code of ethics - comparison CZ and UA

Table 5. Micro-companies (relative frequencies)

\begin{tabular}{|l|c|c|}
\hline \multirow{2}{*}{} & \multicolumn{2}{|c|}{ Presence of a code of ethics } \\
\cline { 2 - 3 } & Yes & No \\
\hline Micro-companies CZ & $12.1 \%$ & $87.9 \%$ \\
\hline Micro-companies UA & $7.1 \%$ & $92.9 \%$ \\
\hline
\end{tabular}

Table 6. Results of the statistical test and the lower limit of the interval estimation

\begin{tabular}{|l|c|}
\hline Testing statistic $Z$ & 0.880 \\
\hline $\mathrm{P}$ - value & 0.190 \\
\hline Lower limit of the interval estimation & -0.043 \\
\hline
\end{tabular}

As the p-value is higher than the significance level of 0.05 , the difference in the proportions of micro-companies with a code of ethics in the Czech Republic and Ukraine is statistically insignificant. The lower limit of the interval estimation is negative, so the zero value lies inside this estimation. In spite of the fact that the deviation from zero is only $4.3 \%$, the test results do not allow us to claim with sufficient confidence that the difference 
in the proportions with regards to the presence of a code of ethics between both countries is statistically significant.

Table 7. Small companies (relative frequencies)

\begin{tabular}{|l|c|c|}
\hline \multirow{2}{*}{} & \multicolumn{2}{|c|}{ Presence of a code of ethics } \\
\cline { 2 - 3 } & Yes & No \\
\hline Small companies CZ & $23.5 \%$ & $76.5 \%$ \\
\hline Small companies UA & $6.5 \%$ & $93.5 \%$ \\
\hline
\end{tabular}

Table 8. Results of the statistical test and the lower limit of the interval estimation

\begin{tabular}{|l|l|}
\hline Testing statistic $\mathrm{Z}$ & 3.132 \\
\hline $\mathrm{P}$ - value & 0.00087 \\
\hline Lower limit of the interval estimation & 0.081 \\
\hline
\end{tabular}

In the case of small companies, the test shows a significant difference. The p-value is significantly less than the significance level of 0.05 and the lower limit of the interval estimation. This shows the extent to which the proportion of companies with a code of ethics in the Czech Republic exceeds that in Ukraine i.e. over 8\% higher. As this is the lower limit, the real difference can potentially be greater still. The questionnaire survey results show 0.17 (i.e. $17 \%$ ).

Table 9. Medium-sized companies (relative frequencies)

\begin{tabular}{|l|c|c|}
\hline \multirow{2}{*}{} & \multicolumn{2}{|c|}{ Presence of a code of ethics } \\
\cline { 2 - 3 } & Yes & No \\
\hline Medium-sized companies CZ & $36.0 \%$ & $64.0 \%$ \\
\hline Medium-sized companies UA & $9.1 \%$ & $90.9 \%$ \\
\hline
\end{tabular}

Table 10. Results of the statistical test and the lower limit of the interval estimation

\begin{tabular}{|c|c|}
\hline Testing statistic Z & 4.986 \\
\hline $\mathrm{P}$ - value & $3.078 \cdot 10^{-07}$ \\
\hline Lower limit of the interval estimation & 0.18 \\
\hline
\end{tabular}

In the group of medium-sized companies, the test results are even more convincing. The p-value is negligibly small; several orders below the significance level. The lower limit of the interval estimation for the difference in the proportions is $18 \%$, while the difference in the frequencies according to the questionnaire is $26.9 \%$. This means that the proportion of Czech companies that have a code of ethics in place is statistically significantly greater than that for Ukrainian companies. 
Table 11. Large companies (relative frequencies)

\begin{tabular}{|l|c|c|}
\hline \multirow{2}{*}{} & \multicolumn{2}{|c|}{ Presence of a code of ethics } \\
\cline { 2 - 3 } & Yes & No \\
\hline Large companies CZ & $67.2 \%$ & $32.8 \%$ \\
\hline Large companies UA & $25.8 \%$ & $74.2 \%$ \\
\hline
\end{tabular}

Table 12. Results of the statistical test and the lower limit of the interval estimation

\begin{tabular}{|l|l|}
\hline Testing statistic $\mathrm{Z}$ & 4.634 \\
\hline $\mathrm{P}$ - value & $1.79 \cdot 10^{-06}$ \\
\hline Lower limit of the interval estimation & 0.267 \\
\hline
\end{tabular}

The situation in the group of large companies is analogous to the previous case. The pvalue is negligibly small; much less than the significance level. The test shows that the difference in the proportion of companies with a code of ethics is statistically significant, which is also backed up by the lower level of the interval estimation for the difference, which is $26.7 \%$. The survey reveals that the proportion of Czech companies with a code of ethics in place is greater than that in Ukraine by no less than $41.4 \%$.

c) Change in proportion of companies with a code of ethics in relation to company size.

Table 13. Proportions obtained from the results of the questionnaire survey

\begin{tabular}{|l|c|c|}
\hline & $\mathrm{CZ}$ & $\mathrm{UA}$ \\
\hline Micro-companies & $12.1 \%$ & $7.1 \%$ \\
\hline Small companies & $23.5 \%$ & $6.5 \%$ \\
\hline Medium-sized companies & $36.0 \%$ & $9.1 \%$ \\
\hline Large companies & $67.2 \%$ & $25.8 \%$ \\
\hline
\end{tabular}

Table 14. Two-sided interval estimations for the proportions of companies with a code of ethics

\begin{tabular}{|l|c|c|}
\hline & $\mathrm{CZ}$ & UA \\
\hline Micro-companies & $(0.077 ; 0.185)$ & $(0.020 ; 0.226)$ \\
\hline Small companies & $(0.179 ; 0.302)$ & $(0.018 ; 0.207)$ \\
\hline Medium-sized companies & $(0.290 ; 0.436)$ & $(0.039 ; 0.196)$ \\
\hline Large companies & $(0.585 ; 0.749)$ & $(0.137 ; 0.432)$ \\
\hline
\end{tabular}




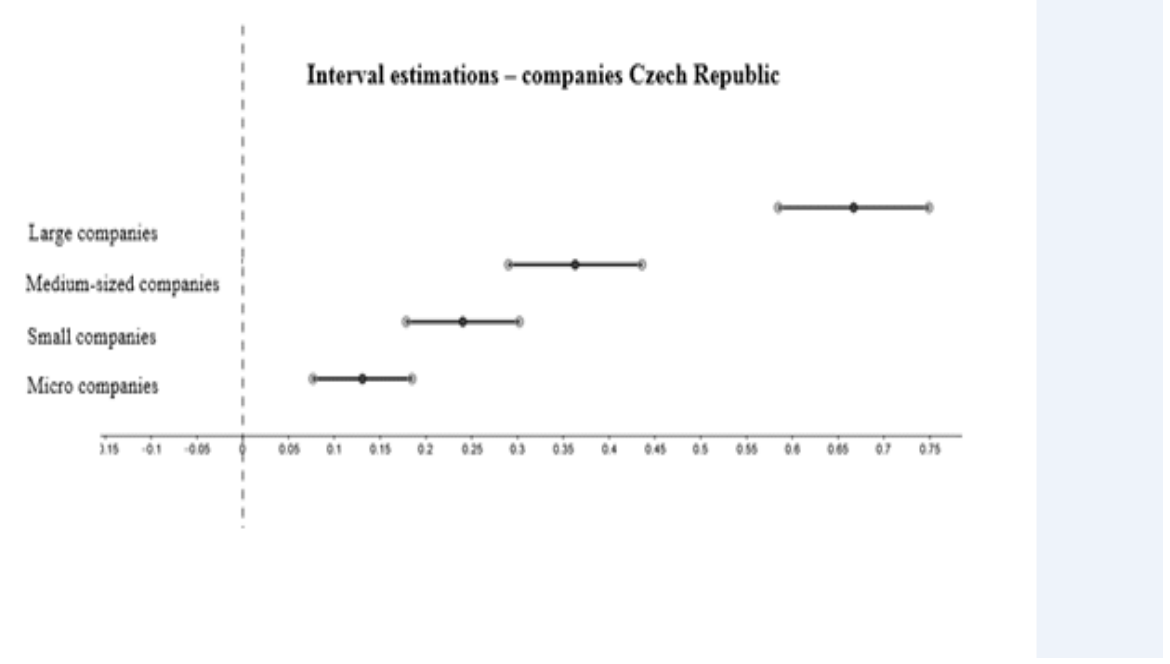

Fig. 1. Interval estimations - companies Czech Republic

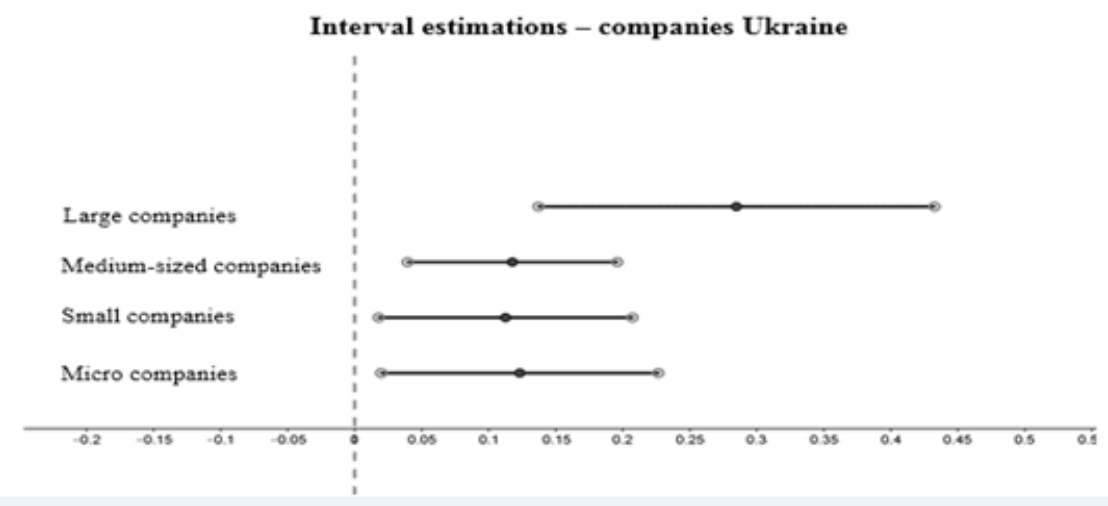

Fig. 2. Interval estimations - companies Ukraine

The results show that the proportion of Czech companies that have a code of ethics in place grows in relation to company size. The situation is clearly represented in Figure 1. The interval estimation is more to the right as the company size grows, with little overlap in the interval estimations. Furthermore, there is a significant distance between large 
companies and the other groups. The grey dots placed on the interval estimations lines represent the proportion of companies with codes of ethics based on the calculations made whilst processing the results of the questionnaire survey. In contrast, the growing trend is not visible among Ukrainian companies. The interval estimations for micro-companies, small companies and medium-sized companies almost completely overlap, with large companies not extending significantly beyond them (see Figure 2). This means that the presence of a code of ethics bears little to no relation to company size in Ukraine. Although a higher proportion is evident for large companies in Ukraine, this is not significant when compared to the Czech Republic.

\section{Conclusion}

The aim of the statistical analysis was to determine whether the proportion of companies that have a code of ethics in place is higher among Czech companies than Ukrainian ones, and whether the proportion grows in relation to company size. Overall, the results show that the presence of a code of ethics is higher among Czech companies, with the exception of micro-companies, where no difference was proven. Among Czech companies, the number of those that have a code of ethics in place grows in relation to company size, with the most significant jump identified among the group of large companies.

In the case of Ukrainian companies, the proportion of those that have a code of ethics in place is so small that it practically does not grow in relation to company size. The only group where the proportion of companies with a code of ethics in place is higher is among the group of large companies. However, when compared to the situation among Czech companies, the difference is incomparably less significant.

\section{Discussion}

Our research has confirmed the assumption that the presence of a code of ethics is lower in Ukraine than in the Czech Republic, which in turn confirms that codes of ethics are attributable to more developed economies, where a more cultured business environment exists. Generally speaking, this also confirms that the presence of a code of ethics in both countries is the greatest among large and medium-sized companies.

It is the opinion of the author that further research is required into the relationship between the level of development of a country's economy and the presence of a code of ethics within companies, and specifically in relation to company size.

\section{References}

1. C. M. F. Ho, O.T. Oladinrin, Evaluation of ethical codes implementation - a fuzzy approach. Facilities [online], Available from: http:/www.emeraldinsight.com/doi/abs/ 10.1108/F-04-2015-0015 (2016)

2. M. Kaptein. The Effectiveness of Ethics Programs: The Role of Scope, Composition, and Sequence. Journal of Business Ethics [online], Available from: http://link.springer.com/article/10.1007/s10551-014-2296-3 (2015)

3. M. Štička et al., Korupce a protikorupční politika ve veřejné správě. Praha: Transparency International - Česká republika, (2008) 
4. S. P. Rogers, J. M. Swales, We the People? An Analysis of the Dana Corporation Policies Document. The Journal of Business Communication, 27(3), 293-313 (1990)

5. L. B. Harman, Ethical challenges in the management of health information. New York: Aspen Publishers, (2001)

6. KPMG, Ethics Survey - 2001: Ethics in Practice [online], Available at: https://www.gov.za/sites/default/files/ethics_0.pdf (2002)

7. Deloitte, Business Ethics and Compliance in the Sarbanes-Oxley Era [online], Available at: https://dart.deloitte.com/resource/1/ed57017b-3f7e-11e6-95db4df6a2b33f51 (2004)

8. Ethics resource center, National business ethics survey: How employees view ethics in their organizations (1994-2005). Washington DC, USA (2005)

9. LRN, The impact of codes of conduct on corporate culture: Measuring the immeasurable [online], Available at: http://www.acc.com/_cs_upload/vl/membersonly/Article/1327042_1.pdf (2006)

10. KPMG, Business Codes of the Global 200: Their Prevalence, Content and Embedding [online], Available at: http://www.ethicsmanagement.info/content/Business $\% 20$ codes $\% 20$ Fortune $\% 20200 . p d$ $\underline{f}(2008)$

11. IBE, Employee Views of Ethics at Work. Institute of Business Ethics. British Survey. [online], Available at: http://www.ibe.org.uk/userfiles/euethicsatwork2012.pdf (2012)

12. CGMA, Managing responsible business 2015 edition: The ethical challenges organizations must navigate to succeed in a connected world. Durham: Chartered Global Management Accountants (2015)

13. Pricewaterhousecoopers, Worldwide Economic Crime Survey - Report for the Czech Republic [Celosvětový průzkum hospodářské kriminality - zpráva za Českou republiku] [online], Available at: https://www.pwc.com/cz/cs/hospodarskakriminalita/assets/pdf/global-economic-crime-survey-2016-cz.pdf (2016)

14. Dow Jones \& Metricstream, Global anti-corruption survey results 2016 [online], Available at: https://dow-jones-2097.docs.contently.com/v/2016-dow-jones-andmetricstream-global-anti-corruption-survey (2016)

15. Transparency International - Czech Republic, Every fifth financial manager in Czech has solved an ethical dilemma in his job [Každý pátý finanční manažer v česku rešil v zaměstnání etické dilema] [online], Available at: https://www.transparency.cz/kazdypaty-financni-manazer-v-cesku-resil-v-zamestnani-eticke-dilema/ (2015)

16. Z. Džbánková, Etické aspekty ekonomického prostředí v ČR v procesu připojování $\mathrm{k}$ EU. Marathon, 49(6), 3-19 (2013)

17. Transparency International - Czech Republic, Ethics code application survey [Průzkum aplikace etických kodexů] [online], Available at: http://transint.xred.cz/doc/ve pruzkum_aplikace etickych_kodexu.pdf (2006)

18. Z. Dytrt, Managerial Ethics in Questions and Answers: Is morale and success in business together? [Manažerská etika v otázkách a odpovědich: jde morálka a úspěch v byznysu dohromady?], Brno: Computer Press (2011)

19. Neovlivní.cz. The state will protect the company from prosecution, but they are lagging behind in the struggle with competitors [Stát ochrání firmy před stíháním, ty přitom v boji s konkurencí zaostávají]. In: Neovlivní.cz [online], Available at: 
http://neovlivni.cz/stat-ochrani-firmy-pred-stihanim-ty-pritom-v-boji-s-korupcizaostavaji/ (2015)

20. Finanční a Ekonomický Institut, Only in less than a quarter of companies follow an ethical code [Jen v necelé čtvrtině firem se řídí etickým kodexem]. In: Finanční a ekonomický institut [online], Available at: https://faei.cz/jen-v-necele-ctvrtine-firemse-ridi-etickym-kodexem/ (2015)

21. Z. Caha, J. Urban, A Code of Ethics as an Organizational Management Tool and its Use in the Czech Republic. Lüdenscheid, Germany: RAM-Verlag, (2017)

22. Z. Caha, M. Vokoun, The impact of the presence of a code of ethics on the economic prosperity of a company. In: Dvouletý,O., M. Lukeš a j. Mísař. Innovation management, entrepreneurship and sustainability 2017. Praha: Oeconomica (2017) 
